\title{
Optimal sizing of solar photovoltaic-Wind hybrid system
}

\author{
Pooja $^{1}$, Dr. Tarlochan Kaur ${ }^{2}$ \\ M.E. Scholar, EED, PEC University of Technology Chandigarh, India ${ }^{1}$ \\ Associate Professor, EED, PEC University of Technology, Chandigarh, India ${ }^{2}$
}

\begin{abstract}
Increase in energy demand has made the renewable resources more attractive. Additionally, use of renewable energy sources reduces combustion of fossil fuels and the consequent $\mathrm{CO} 2$ emission which is the principal cause of global warming. The concept of photovoltaic-Wind hybrid system is well known and currently thousands of PV-Wind based power systems are being deployed worldwide, for providing power to small, remote, grid-independent applications. This paper shows the way to design the aspects of a hybrid power system that will target remote users. It emphasizes the renewable hybrid power system to obtain a reliable autonomous system with the optimization of the components size and the improvement of the cost. The system can provide electricity for a remote located village. The main power of the hybrid system comes from the photovoltaic panels and wind generators, while the batteries are used as backup units. The optimization software used for this paper is HOMER.

HOMER is a design model that determines the optimal architecture and control strategy of the hybrid system. The simulation results indicate that the proposed hybrid system would be a feasible solution for distributed generation of electric power for stand-alone applications at remote locations
\end{abstract}

Keywords: - Fuel Cell; HOMER; Optimization; Photovoltaic panel; Wind Generator

\section{INTRODUCTION}

Commonly hybrid energy systems use solar, wind, and hydro energy sources, although most of the renewable energy available on earth consists of different forms of solar energy. A system of the combination of these different sources has the advantage of the balance and stability [1]. The concept of photovoltaic (PV) is well understood and currently thousands of PV-based power systems are being deployed worldwide, for providing power to small, remote, grid-independent applications [2]. Despite abundant availability of solar/wind energy, a PV or Wind Generator (WG) stand-alone system cannot satisfy the loads on a 24-hour basis [3]. Often, the variations of solar/wind energy generation do not match the time distribution of the load. Therefore, power generation systems dictate provision of battery storage facility to dampen the time distribution mismatch between the load and solar/wind energy generation and to facilitate for maintenance of the systems [4]. PV and WG generated electricity stored in batteries can be retrieved during nights. Also use of Fuel Cell (FC) system with $\mathrm{PV} / \mathrm{WG} /$ battery reduces battery storage requirement.

Energies have made a fast and significant breakthrough in the past 10 years. In addition, they can be consumed locally, hence reducing both impacts from high-voltage transmission lines through rural and urban landscapes and power losses. However, neither a solar nor a wind energy stand-alone system can fully satisfy load consumption because of seasonal and periodic climatic variations. Therefore it is more reliable and efficient to install a hybrid energy system with storage because of renewable energy sources intermittent character[4]. In particular, advances in wind and photovoltaic (PV) generation technologies have increased their use in wind-alone, PValone, and hybrid PV-wind configurations[5].
Wind speeds are often low in periods (summer, eventually) when the sun resources are at their best. On the other hand, the wind is often stronger in seasons (the winter, in many case) when there are less sun resources. Even during the same day, in many regions worldwide or in some periods of the year, there are different and opposite patterns in terms of wind and solar resources. And those different patterns can make the hybrid systems the best option in electricity production There has traditionally been two different types of solar systems - On Grid and Off Grid.

Off Grid system allows them to be completely self sufficient. Off Grid is also called Remote Power or Stand Alone .For increasing the reliability and continuity of supply, they are still connected to the grid, and the purpose of their solar is to either feed back into the grid (called a Gross Feed tariff) or to provide power for a home to lower its power bill (Net Feed Tariff).On Grid is also called Grid-Connect or Grid-Interactive

There are numerous possible applications for hybrid power systems. The most common examples are:

1.Central grid connected hybrid systems (CGHS)

2.Isolated grid hybrid systems (IGHS)

3.Isolated or special purpose hybrid systems (ISHS)

\section{RELATED WORK}

Various aspects must be taken into account when working with stand-alone hybrid systems for the generation of electricity. Reliability and cost are two of these aspects; it is possible to confirm that hybrid stand-alone electricity generation systems ar usually more reliable and less costly than systems that rely on a single source of energy $[5,6]$. In various research papers [7-9], it has been proven that hybrid renewable electrical systems in offgrid applications 
are economically viable, especially in remote locations. In addition, climate can make one type of hybrid system more profitable than another type. For example, photovoltaic hybrid systems (Photovoltaic-DieselBattery) are ideal in areas with warm climates [10].

On the other hand, various mathematical models of the elements that make up these systems have been used, as well as various design and simulation models. The complexity of the models of the components of the hybrid systems mainly depends on the type of application (simulation, design, etc.). The models usually used for the components of the most common hybrid systems (photovoltaic, wind, diesel and batteries) are shown in [11]. This paper will review the simulation and design models of the hybrid systems that have been used up to this moment in time, indicating which tools have been developed for this purpose.

\section{SYSTEM DESCRIPTION}

A $6 \mathrm{kWp}$ solar - wind hybrid system consisting of 1 $\mathrm{kWp}$ solar PV, $5 \mathrm{~kW}$ wind turbine, $4 \mathrm{~kW}$ converter and 150 Ah battery bank, is installed at Sanodar village in Bhavnagar district (latitude : $29^{\circ} 36^{\prime} \mathrm{N}$, and longitude : $53^{\circ} 40^{\circ}{ }^{\circ} \mathrm{E}$ in GMT + 5:30 time zone, altitude : $892.7 \mathrm{~m}$ above sea level).

Among the various districts of Gujarat, Sanodar village in Bhavnagar district has been selected due to abundant wind and solar energy. Sanodar is a Village in Bhavnagar District of Gujarat State, India. It is located $27 \mathrm{KM}$ towards South from District headquarters Bhavnagar. It is located $20 \mathrm{~km}$ from Ghogha and $224 \mathrm{~km}$ from State capital Gandhinagar.

On the design point of view, the optimization of the size of hybrid plants is very important, and leads to a good ratio between cost and performances. Before the system sizing, load profile and available insolation should be evaluated.

\section{A. $\quad$ Solar Radiation and Wind Speed Data}

In the present work, solar radiation and wind speed data collected from real case near sanoder (Gujarat, 29 $36^{\prime} \mathrm{N}$, $\left.53^{\circ} 40^{\prime} \mathrm{E}\right)$. This data has been analyzed to assess utilization of hybrid PV/WG/battery/FC power systems to meet the load requirements of a typical remote village. As shown in Fig. 1 the monthly average daily solar radiation of $5.212(\mathrm{kWh} / \mathrm{m} 2)$. Fig. 2 shows the monthly average daily wind speed of $6.54 \mathrm{~m} / \mathrm{s}$.

\section{B. Load Profile}

An important consideration of any power generating system is load. As a case study and as a representation of remote village which lack access to the utility grid, the measured annual average energy consumption has been considered to scale the load to $6(\mathrm{kWh} / \mathrm{d})$ in the present study. The peak requirements of the load dictate the system size. In this study $1.5(\mathrm{~kW})$ has been considered to scale peak load.

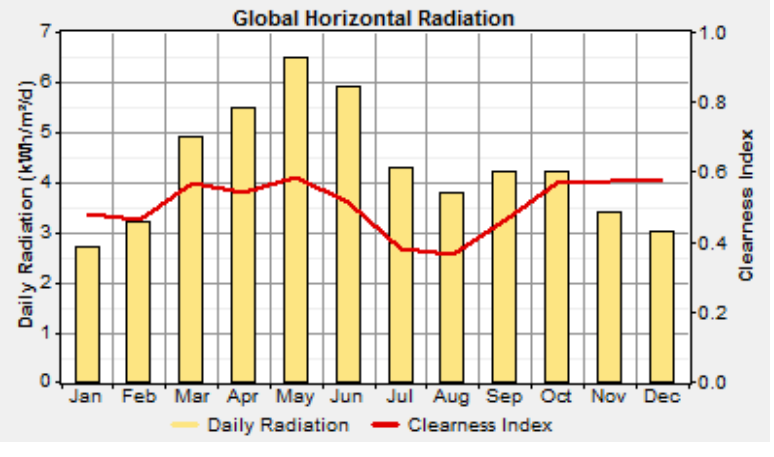

Fig. 1. Yearly average daily solar radiation.

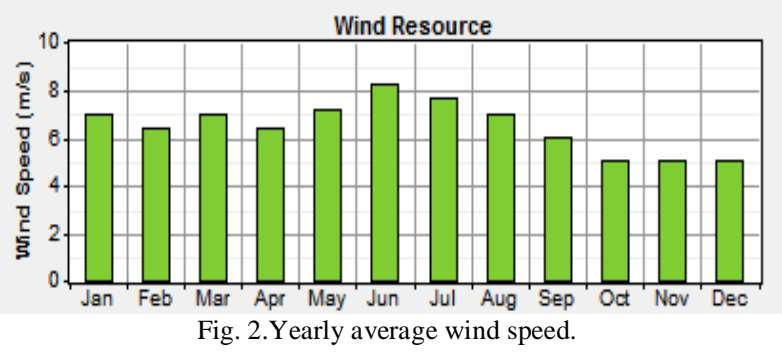

IV. Methodology

In order to design a mini-grid hybrid power system, one has to be provided with information for the selected location. Typical information's required are; the load profile that should be met by the system, solar radiation for PV generation, wind speed for the wind power generation, initial cost for each component (diesel, renewable energy generators, battery, converter), annual interest rate, project lifetime, etc. Then using these data one can perform the simulation to obtain the best hybrid power system configuration. One of the available tools for this purpose is the HOMER software from NREL.

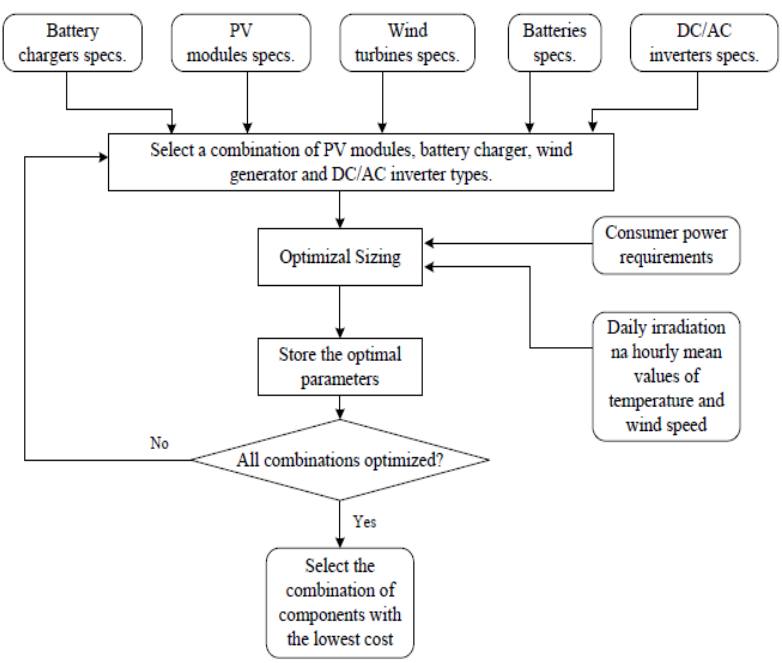

Fig.3 Flow Chart for Sizing of system[12]

The analysis of the surplus renewable power is made on a hourly basis, comparing the available renewable power previously calculated to the electric load. Then it is decided what to do with this energy excess, changing the system configuration so that little or zero renewable 
surplus exists. After it has completed one year calculation, in its optimization process. [13]. In this study, decision it is determined whether the system configuration fulfills Variables include:

the constraints imposed by the modeler. If the system is viable, the software estimates the life-cycle cost taking into account, i.e. annual fuel consumption, generator operating hours and expected battery life. The total net present cost (NPC) is used as the measurement to represent the life-cycle cost of a particular system. The NPC includes investment costs, operation, maintenance and replacement costs that take place within the project lifetime, always discounting future cash flows to the present date.[12]

After the simulation process has been conducted to search for viable system configurations, the optimization process determined the best possible system configurations within the simulation solutions. The best possible, or optimal solutions, are those who satisfy user's specified constraints at the lowest possible NPC. To all feasible solutions, a rank is assigned according to the NPC and the one with the lowest NPC is considered as the optimal system configuration.[12]

For a sensitive analysis, the software aim is to reveal how will the outputs of the problem change, when changes occur in the inputs. The user is able to enter a range of values for sensitivity variables like the fuel price, the lifetime of a PV array or wind turbine, the grid power price, among others. It is also allowed changing the magnitude of an hourly data set, such as load an renewable resource in study. All this sensitive analysis are optimized once again for a better long term knowing of systems behavior, permitting the user to deal with uncertainties and thus making better design decisions.[12]

\section{v. HOMER SIMULATION MODEL}

In the present work, the selection and sizing of components of hybrid power system has been done using NREL's HOMER software. HOMER is a general purpose hybrid system design software that facilitates design of electric power systems for stand-alone applications. Input information to be provided to HOMER includes: electrical loads (one year of load data), renewable resources, component technical details and costs, constraints, controls, type of dispatch strategy, etc. HOMER designs an optimal power system to serve the desired loads.[13]

HOMER is a simplified optimization model, which performs hundreds or thousands of hourly simulations over and over (to ensure best possible matching between supply and demand) in order to design the optimum system. It uses life cycle cost to rank order these systems . The model has been developed using HOMER, consists of a PV, WG(s), a battery. The schematic of this hybrid power system is shown in Fig.4 . In order to verify the system performance under different situation, simulation studies have been carried out using real weather data (solar irradiance and wind speed). The goal of the optimization process is to determine the optimal value of each decision variable that interests the modeler. A decision variable is a variable over which the system designer has control and for which HOMER can consider multiple possible values
The size of the PV array

The number of WG

The Capacity of batteries

The size of the DC/AC converter

In normal operation, PV and WG feed the load demand. The excess energy from PV and WG is stored in the battery until full capacity of the battery is reached. The main purpose of introducing battery storage is to import/export energy depending upon the situation. In the event, the output of PV and WG exceeds the load, the excess energy is fed to battery or goes unused (due to lack of demand).

The objective of the optimization is to minimize the net present cost (NPC) of the system with $0 \%, 10 \%$ and $20 \%$ capacity shortage and state of charge of battery bank should not be less than $80 \%$. The formulated objective function with constraints is given by Eq. (1).

Min $\sum$ NPC

Constraints: $80 \% \leq S O C \leq 100 \%$

Capacity Shortage $=0 \%, 5 \%, 10 \%$ and $20 \%$

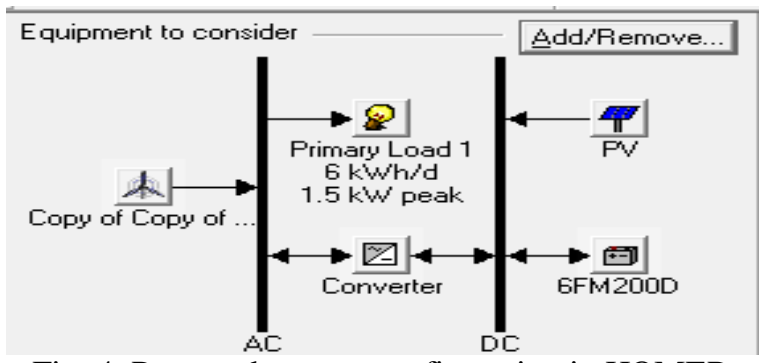

Fig. 4. Proposed system configuration in HOMER

\section{SIMULATION RESULTS}

Several simulations have been made by considering different PV capacities and the number of WG. Sensitivity Analysis is made for different wind speeds.

\section{a. $\quad$ Wind Speed}

Results for different wind speeds are analysed .In Fig $5 a$, wind speed is taken as $6.5 \mathrm{~m} / \mathrm{s}$.Optimised NPC is obtained as $\$ 21,181$. In Fig 5b,wind speed is taken as $4 \mathrm{~m} / \mathrm{s}$. Optimised NPC is obtained as $\$ 26,238$. In Fig $5 \mathrm{c}$, wind speed is taken as $3 \mathrm{~m} / \mathrm{s}$. Optimised NPC is obtained as $\$ 27,961$.So as speed of wind decreases,NPC increases.

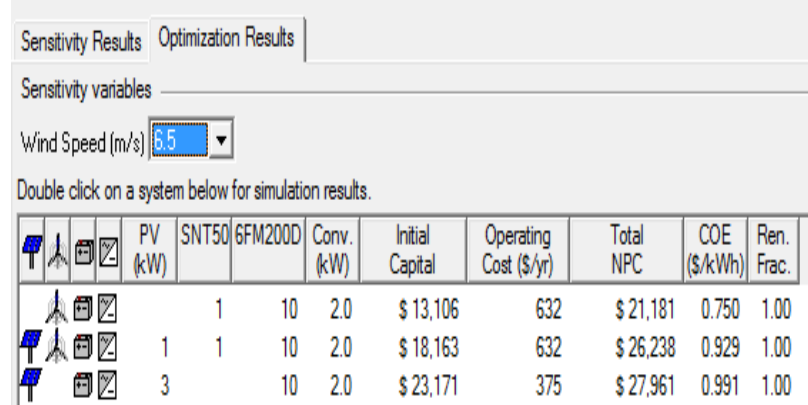

Fig. 5a. Results for wind speed $6.5 \mathrm{~m} / \mathrm{s}$ 


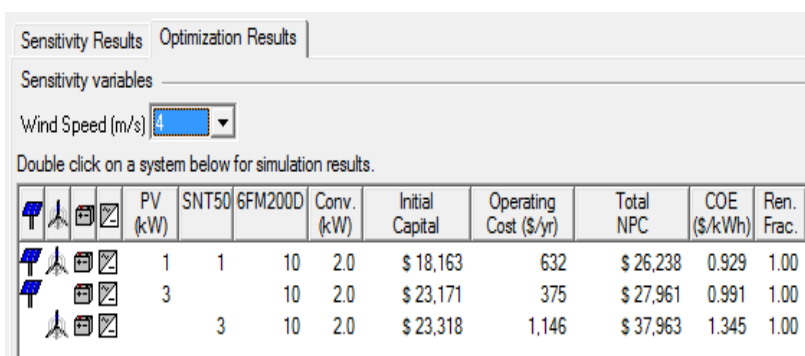

Fig. 5b. Results for wind speed $4 \mathrm{~m} / \mathrm{s}$

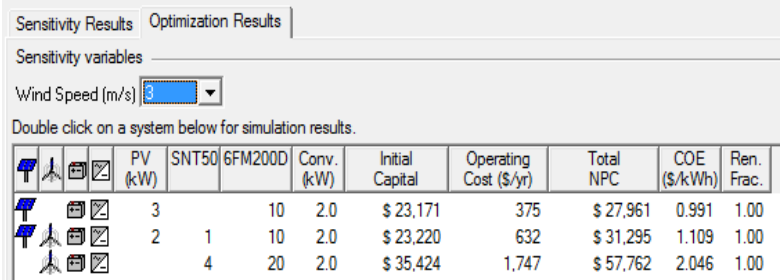

Fig. 5c. Results for wind speed $3 \mathrm{~m} / \mathrm{s}$

The sensitivity of the effect of wind speed on cost parameters, Total Net Present Cost (TNPC), Cost of Electricity of complete system is analysed. As wind speed decreases from $6.5 \mathrm{~m} / \mathrm{s}$ to $3 \mathrm{~m} / \mathrm{s}$ all the cost parameters are increasing due to increase in optimal system size according to available resources. These are shown in figures $5 \mathrm{a}, 5 \mathrm{~b}, 5 \mathrm{c}$.

A. As wind potential is very high in this region,when optium combination with wind turbine is analysed,excess electricity production is very high as compared to combination without wind turbine.

B. The best optimum combination as per NPC is found to be combination without wind turbine because its installation cost is very high as compared to solar panel.

\section{b. Capacity shortage}

An capacity shortage is a shortfall that occurs between the required operating capacity and the actual amount of operating capacity the system can provide. HOMER keeps track of such shortages and calculates the total amount that occurs over the year

Various combinations are analysed as per load requirements,resources available and economics for $0 \%, 10 \%, 20 \%$ capacity shortage.

\section{System with 0\% capacity shortage:}

The best result for $0 \%$ capacity shortage is found to be a $1 \mathrm{kWp}$ PV array, $2 \mathrm{~kW}$ inverter, 10 batteries with net present cost (NPC) as \$27,961 and levelized cost as $\$ 0.991 / \mathrm{kWh}$. The total annual electric production of this system is obtained as $19,784 \mathrm{kWh} / \mathrm{yr}$ out of which $8 \%$ is produced by solar source and rest by wind turbine. $88.5 \%$ $(17,510 \mathrm{Wh} / \mathrm{yr})$ electricity, is produced in excess. The excess electricity production is very high for a $100 \%$ reliable or $0 \%$ capacity shortage system which can be utilized by serving deferrable load. A deferrable load is the load which can be deferred over time and can be served during the time of excess electricity production. The use of waste electricity in deferrable load doesn't affect the reliability of the system; moreover, the cost of energy will also reduce. Thus, it is advantageous to use deferrable load in reliable renewable energy systems.Its shown in fig 6a.

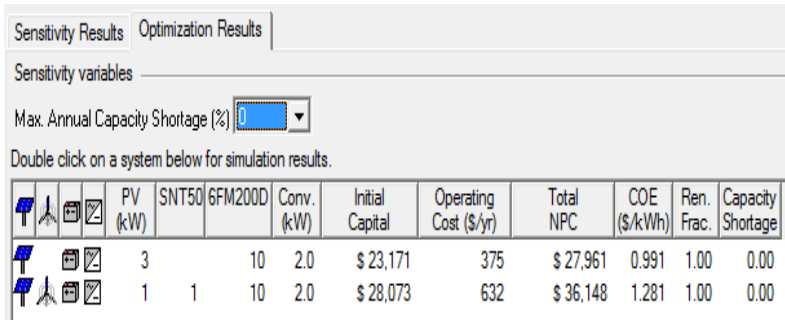

Fig. 6a. Optimisation Results for Capacity Shortage 0\%

\section{System with $10 \%$ capacity shortage:}

The best optimised combination involves a $2 \mathrm{~kW} P V$ array, $1 \mathrm{~kW}$ inverter, $1 \mathrm{kw}$ rectifier, 10 batteries with net present cost (NPC) as $\$ 22,213$ and levelized cost as $\$ .797 / \mathrm{kWh}$. The total annual electric production of this system is obtained as $3,223 \mathrm{kWh} / \mathrm{yr}$ out of which $21 \%$ electricity, is produced in excess.

In order to utilize both solar and wind resource of the site, the optimized combination for this location, is found to be as one $5 \mathrm{kWp}$ wind turbine and $2 \mathrm{kWp}$ PV system with 1 string of 10 batteries. The $\mathrm{COE}$ of the system will be $1.051 / \mathrm{kWh}$ with $89.9 \% \quad(19,237 \mathrm{kWh} / \mathrm{yr})$ excess electricity production with $7.5 \%$ capacity shortage. Results shown in fig. $6 \mathrm{~b}$

\begin{tabular}{|c|c|c|c|c|c|c|c|c|}
\hline \multicolumn{9}{|c|}{ Sensitivity Results Optimization Results } \\
\hline \multicolumn{9}{|c|}{ Sensitivity variables } \\
\hline \multicolumn{9}{|c|}{ Max. Annual Capacity Shottage (\%) 10} \\
\hline \multicolumn{9}{|c|}{ Double click on a system below for simulation results. } \\
\hline 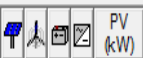 & SNT50 6FM200D & $\begin{array}{l}\text { Conv. } \\
(\mathrm{kW})\end{array}$ & $\begin{array}{l}\text { Intial } \\
\text { Capital }\end{array}$ & $\begin{array}{l}\text { Operating } \\
\text { Cost (S/yr) }\end{array}$ & $\begin{array}{l}\text { Total } \\
\text { NPC }\end{array}$ & $\left.\begin{array}{|c|}\operatorname{COE} \\
(S / k W h)\end{array}\right)$ & \begin{tabular}{|l|} 
Ren. \\
Frac.
\end{tabular} & $\begin{array}{l}\text { Capacty } \\
\text { Shortage }\end{array}$ \\
\hline 甲 & 10 & 1.0 & $\$ 17,614$ & 360 & $\$ 22,213$ & 0.797 & 1.00 & 0.03 \\
\hline & 1 & 0.5 & $\$ 25,380$ & 264 & $\$ 28,761$ & 1.051 & 1.00 & 0.08 \\
\hline 甲人同 & 10 & 0.5 & $\$ 27,323$ & 609 & $\$ 35,111$ & 1.261 & 1.00 & 0.04 \\
\hline
\end{tabular}

Fig. 6b. Optimisation Results for Capacity Shortage 10\%

2. System with $10 \%$ capacity shortage:

The best optimised combination involves a $4 \mathrm{~kW}$ PV array, $1 \mathrm{~kW}$ converter with net present cost (NPC) as $\$ 20,919$ and levelized cost as $\$ .849 / \mathrm{kWh}$ and excess electricity of $66.8 \%$.Optimised results are shown in fig6c.

\begin{tabular}{|c|c|c|c|c|c|c|c|c|}
\hline \multicolumn{9}{|c|}{ Sensitivity Results Optimization Results } \\
\hline \multicolumn{9}{|l|}{ Sensitivity variables - } \\
\hline \multicolumn{9}{|c|}{ Max. Annual Capacity Shottage (\%) 20} \\
\hline \multicolumn{9}{|c|}{ Double click on a system below for simulation results. } \\
\hline 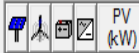 & SNT50 6FM2000 & $\begin{array}{l}\text { Conv. } \\
k W)\end{array}$ & $\begin{array}{l}\text { Initial } \\
\text { Capital }\end{array}$ & $\begin{array}{l}\text { Operating } \\
\left.\text { Cost }(\$ / y)^{\prime}\right)\end{array}$ & $\begin{array}{l}\text { Total } \\
\text { NPC }\end{array}$ & $\begin{array}{c}\mathrm{COE} \\
(\mathrm{S} / \mathrm{kWh})\end{array}$ & $\begin{array}{l}\text { Ren. } \\
\text { Frac. }\end{array}$ & $\begin{array}{l}\text { Capacity } \\
\text { Shortage }\end{array}$ \\
\hline 里息 4 & & 1.0 & $\$ 20,728$ & 15 & $\$ 20,919$ & 0.849 & 1.00 & 0.20 \\
\hline 国图 & 10 & 1.0 & $\$ 17,614$ & 360 & $\$ 22,213$ & 0.797 & 1.00 & 0.03 \\
\hline 果要 & 1 & 0.5 & $\$ 20,323$ & 264 & $\$ 23,704$ & 0.877 & 1.00 & 0.11 \\
\hline 䎡人国园 & 1 & 0.5 & $\$ 27,323$ & 609 & $\$ 35.111$ & 1.261 & 1.00 & 0.04 \\
\hline
\end{tabular}

Fig. 6c. Optimisation Results for Capacity Shortage 20\% 
Table 1. Results for different cases of capacity shortage hybrid system

\begin{tabular}{|c|c|c|c|}
\hline $\begin{array}{c}\% \\
\text { Capacity } \\
\text { shortage }\end{array}$ & NPC & $\begin{array}{c}\text { Levelized } \\
\text { Cost }\end{array}$ & $\begin{array}{c}\text { Excess } \\
\text { Electricity }\end{array}$ \\
\hline $0 \%$ & $\$ 27,961$ & $\$ .991 / \mathrm{kwh}$ & $47.3 \%$ \\
\hline $10 \%$ & $\$ 22,213$ & $\$ .797 / \mathrm{kwh}$ & $21 \%$ \\
\hline $20 \%$ & $\$ 20,919$ & $\$ .849 / \mathrm{kwh}$ & $66.8 \%$ \\
\hline
\end{tabular}

Table1 shows that as \%Capacity Shortage increases,system has to produce less excess electricity and components required are less.So cost of system i.e. NPC and levelized Cost decreases.

\section{CONCLUSION}

The solar-wind hybrid systems will be reliable systems for residential/Institutional buildings both in urban and rural locations in the Western Himalayan region. A system with some acceptable capacity shortage value is more economical.Because when capacity shortage s very less.Almost of load is to be met by system sourcs. So resources need to be increased and hence cost increases. Defferable load can be served to utilize the excess electricity produced. It is analysed that $2 \mathrm{kw}$ solar system is more cost efficient than solar-wind system because of wind turbine cost but the idea of utilising wind energy in off grid rural areas is also very important where sufficient wind resource is available

\section{ACKNOWLEDGMENT}

Pooja Jain would like to thanks the guidance and mentorship of Dr. Tarlochan Kaur.

\section{REFERENCES}

[1] R. Ramaku mar, I. Abouzahr, and K. Ashenayi, 'A KnowledgeBased Approach to the Design of Integrated Renewable Energy Systems', IEEE Trans. on Energy Conversion, vol. 7, No. 4,pp.64859, Dec. 1992.

[2] R. Chedid, H. Akiki, and S. Rahman, 'A Decision Support Technique for the Design of Hybrid Solar-Wind Power Systems', IEEE Trans.on Energy Conversion,vol. 13, No. 1,pp.7352-67, Mar. 1998.

[3] W.D. Kellogg, M.H. Nehrir, V. Gerez, and G. Venkataramanan, 'Generation Unit sizing and Cost Analysis for Stand-Alone Wind, Photovoltaic, and Hybrid Wind/PV Systems', IEEE Trans. on Energy Conversion, vol. 13, No. 1,pp. 70-75,Mar. 1998

[4] F. Giraud, and Z.M. Salameh, 'Steady-State Performance of a GridConnected Rooftop Hybrid Wind-Photovoltaic Power System with Battery Storage',IEEE Trans. on Energy Conversion, vol. 16, No. 1,pp.1-7, Mar. 2001.

[5] Muselli M, Notton G, Louche A. Design of hybrid-photovoltaic power generator with optimization of energy management. Solar Energy 1999;65(3): 143-57.

[6] Bagen, Billinton R. Evaluation of different operating strategies in small standalone power systems. IEEE Trans Energy Convers 2005;20(3):654-60.

[7] Elhadidy MA, Shaahid SM. Parametric study of hybrid (wind + solar + diesel) power generating systems. Renew Energy 2000;21(2):129-39.

[8] Gutie' rrez Vera J. Options for rural electrification in Mexico. IEEE Trans Energy Convers 1992;7(3):426-30.

[9] Wichert B. PV-Diesel hybrid energy systems for remote area power generation - a review of current practice and future developments. Renew Sustain Energy Rev 1997;1(3):209-28.
[10] Shaahid SM, Elhadidy MA. Opportunities for utilization of standalone hybrid (photovoltaic + diesel + battery) power systems in hot climates. Renew Energy 2003;28(11):1741-53.

[11] Deshmukh MK, Deshmukh SS. Modeling of hybrid renewable energy systems. Renew Sustain Energy Rev 2008;12(1):235-49.

[12] "Design Optimization of Stand-AloneHybrid Energy Systems" ,Francisco Gonçalves Goiana Mesquita

[13]. Ahmad Rohani,'Modeling of a Hybrid Power System for Economic Analysis and Environmental Impact in HOMER, "IEEE Trans Energy".

[13] Satish Kumar Ramoji1, B.Jagadish Kumar2, 'Optimal Economical sizing of a PV-Wind Hybrid Energy System using Genetic Algorithm and Teaching Learning Based Optimization', International Journal of Advanced Research in Electrical, Electronics and Instrumentation Engineering,Vol. 3, Issue 2, pp.7352-67.February 2014.

[14] Essam A. Al-Ammar, Nazar H. Malik, 'Application of Using Hybrid Renewable Energy in Saudi Arabia', Vol. 1, No. 4, pp.84-89,2011

[15] B.S. Borowy, Z.M. Salameh, 'Methodology for Optimally Sizing the Combination of a Battery Bank and PV Array in a Wind/PV Hybrid System',IEEE Trans. on Energy Conversion, vol. 11, No. 2,pp.367-75,Jun. 1996.

[16] S. Jalilzadeh, A. Rohani, H. Kord, and M. Nemati, 'Optimum design of a hybrid Photovoltaic/Fuel Cell energy system for standalone applications',IEEE Int. Conf. on Electrical Engineering, and Electronics (ECTI), vol. 1, pp. 152-155, Thailand, May 2009.

[17] National Renewable Energy Laboratory.Available: http://www.nrel.gov/international/tools/HOMER/homer.html

[18] NASA Surface Meteorology and Sola Energy [Online]. Available: http://www.nasa.gov

[19] Caisheng Wang, and M. Hashem Nehrir, 'Power Management of aStand-Alone Wind/Photovoltaic/Fuel Cell Energy System', IEEE Trans. on Energy Conversion, Vol. 23, No. 3,pp.957-66, Sep. 2008.

[20] S.M. Shaahid, and M.A. Elhadidy, 'Economic analysis of hybrid photovoltaic-diesel-battery power systems for residential loads in hot regions-A step to clean futur', Renewable and Sustainable Energy Reviews, pp.488-503, 2008. 